\section{Correspondence}

http://dx.doi.org/10.11646/zootaxa.4000.1.8

http://zoobank.org/urn:Isid:zoobank.org:pub:B6492A4A-6BBC-4608-A925-9DBCB5631DB0

\title{
The tadpole of Chiasmocleis schubarti Bokermann, 1952 (Amphibia, Anura: Microhylidae)
}

\author{
MARCUS THADEU T. SANTOS ${ }^{1,3}$, TIAGO L. PEZZUTI ${ }^{1}$, FELIPE S. F. LEITE ${ }^{2} \&$ PAULO C. A. GARCIA ${ }^{1}$ \\ ${ }^{1}$ Laboratório de Herpetologia, Departamento de Zoologia, Instituto de Ciências Biológicas, Universidade Federal de Minas Gerais, \\ 31270-901, Belo Horizonte, Minas Gerais, Brazil \\ ${ }^{2}$ Universidade Federal de Viçosa, Campus Florestal, Florestal, Minas Gerais, Brazil \\ ${ }^{3}$ Corresponding author.E-mail mthadeusantos@gmail.com
}

The genus Chiasmocleis Méhely comprises 29 species distributed from Panama to tropical South America clustered in five clades: C. albopunctata, C. bassleri, C. hudsoni, C. shudikarensis and C. ventrimaculata (Peloso et al. 2014). Chiasmocleis schubarti Bokermann belongs to the C. albopunctata clade, which also includes C. alagoana Cruz, Caramaschi, and Freire, C. albopunctata (Boettger), C. capixaba Cruz, Caramaschi, and Izecksohn, C. lacrimae Peloso, Sturaro, Forlani, Gaucher, Motta, and Wheeler, C. leucosticta (Boulenger), and possibly other morphologically and/or molecularly related species that have never been included in a phylogenetic analysis in a broader context (e.g., $C$. atlantica Cruz, Caramaschi and Izecksohn, C. cordeiroi Caramaschi \& Pimenta, C. crucis Caramaschi \& Pimenta, C. gnoma Canedo, Dixo and Pombal and C. mantiqueira Cruz, Feio and Cassini) (Cruz et al. 2007). Within these species, $C$. alagoana, C. albopunctata, C. lacrimae, C. leucosticta and C. mantiqueira have their larval forms described (Wogel et al. 2004; Nascimento \& Skuk 2006; Oliveira-Filho \& Giaretta 2006; Langone et al. 2007; Santana et al. 2012).

Chiasmocleis schubarti is known from Atlantic forest fragments in the states of Espírito Santo, Minas Gerais and Bahia, eastern Brazil (Pimenta \& Silvano 2002). Herein, we describe its tadpole.

Tadpoles of $C$. schubarti (stages 27-42; Gosner 1960) were collected in a temporary pond, surrounded by semideciduous gallery forest, at Parque Estadual do Pico do Itambé $\left(43^{\circ} 18^{\prime} 27^{\prime}\right.$ 'S, $18^{\circ} 25^{\prime} 15^{\prime}$ 'W; $1080 \mathrm{~m}$ a. s. 1.; Datum WGS 84), County of Santo Antônio do Itambé, state of Minas Gerais, at the southeastern portion of the Espinhaço Range, southeastern Brazil, in December 2012. Presence in our samples of pre-metamorphic tadpoles already exhibiting small irregular white blotches on outer surfaces of arms and forearms, also present in adults (in preservative), allowed us to confirm species identity. Moreover, C. schubarti is the only Microhylidae species known for this locality.

We euthanized tadpoles in 5\% lidocaine, then fixed and preserved in $10 \%$ formalin. Voucher lots are housed in the Tadpole Collection of the Universidade Federal de Minas Gerais (UFMG), Belo Horizonte, state of Minas Gerais, Brazil. External morphology descriptions, measurements and proportions were based on 38 tadpoles in stages 34-38 (lots UFMG 1545 and 1563). Terminology and measurements follow Altig \& McDiarmid (1999) and Pinheiro et al. (2012): total length (TL), body length (BL), tail length (TAL), maximum tail height (MTH), tail muscle height (TMH), tail muscle width (TMW), interorbital distance (IOD), body height (BH), body width (BW), body width at eyes level (BWE), eye diameter (ED), eye-snout distance (ESD), oral apparatus width (OAW), dorsal fin height (DFH), ventral fin height (VFH) and dorsal-fin insertion angle (DFiA). All measurements were taken with aid of ImageTool version 3.00. To obtain high quality photos we used an adjustable platform to support tadpoles immersed on water. Values are presented as mean $\pm \mathrm{SD}$ (range).

Data about morphological features of known tadpoles of the C. albopunctata clade and of a morphologically similar species (C. mantiqueira) were obtained from their original descriptions. For Chiasmocleis mantiqueira the lot UFMG 1283 was also analyzed.

Description. Maximum total length $20.6 \mathrm{~mm}$, at stage 38. Body depressed $(\mathrm{BH} / \mathrm{BW}=0.69-0.76)$, rounded in dorsal view, triangular depressed in lateral view, from 0.32 to 0.38 times total length (Fig. 1A, B). Snout semicircular in dorsal view, and slightly rounded in lateral view. Eyes from 0.14 to 0.18 times body width, laterally located (IOD/BWE $=1.00)$. Nares absent. A dorsal nasolacrimal groove from anterior margin of the eye to anterior region of snout (Fig. 1D). Spiracle midventral on lower abdomen, broad-opening in posterior third of the body (anteriorly to vent tube). Its external wall projecting over the vent tube, and with lateral flaps extending in direction to limbs (Fig. 1F). Intestinal tube circularly coiled, switchback point located at center of abdominal region. Vent tube medial, posteroventrally directed 